\title{
Medical Volunteerism in Undergraduate Medical Programme: A Novel, in-depth Curriculum
}

\author{
Adegoke Olusegun Adefolalu
}

\begin{abstract}
Health disparities persist among several populations globally and doctors are well-placed to advocate for better health outcomes among the population they serve thereby promoting health equity. According to the literature, medical educators have the capacity to produce socially responsible medical doctors who have competency in health advocacy in addition to their clinical knowledge. However, apart from being taught the determinants of health, little, or no real-live experience is given to medical students in social medicine and health advocacy to enable them to develop the necessary skills in this area. At the Sefako Makgatho Health Sciences University in Pretoria, South Africa, Medical Volunteerism was offered as a selective course during the 2016 academic year. It entails engagement of the medical students in activities that tied them with the primary burden of providing service to an identified community, where they plan and participate in an organized activity that meets the identified needs of such community. This article describes the structure, content, and outcomes of this curriculum. The feedback from students and other stakeholders were strongly positive, the students rated the course highly in a variety of instances, including appropriateness of lecture topics, presentation of the course contents, course materials, effectiveness of teaching and level of students' participation. The average overall rating for the course was 8.4 based on a ten-point scale. Furthermore, the students acknowledged that it contributed to their personal development in terms of social activism in health. In conclusion, medical volunteerism selective has positive impact that is measurable, support should be given to students and facilitators who are interested in implementing similar selective as it has the potential of reinforcing certain values in medical students that could motivate them to have increased desire to work with underserved communities after graduation.
\end{abstract}

Keywords-Selective; health advocacy; medical curriculum; medical volunteerism; undergraduate medical students

\section{INTRODUCTION}

Globally, widespread inequalities and health disparities persist in many populations, and often a times, these are intricately linked with various socio-economic and political factors peculiar to the population in question. Doctors are well-placed to effect change in the communities they serve because they gain certain unique perspective from experiencing how these inequalities result in poor health outcomes [1]. It is believed that the perspective of the doctors from their experience of health disparities together with their clinical knowledge would equip them to an advocate for these patients $[1,2,3]$. According to the literature, medical educators have the capacity to align the medical curriculum such that the system would produce many generations of socially responsible doctors who have skills and competency in health advocacy in addition to their clinical knowledge $[2,4]$. However, apart from being taught the determinants of health, little, or no real-live experience is given to undergraduate medical students in social medicine and health advocacy in most medical programmes to enable them to develop the necessary skills in this area [4-8]. To address this gap, the author designed and implemented a new social medicine and health advocacy curriculum at the Sefako Makgatho Health Sciences University in Pretoria [4,9]. The objectives of this article are to describe the organizational features of the medical volunteerism selective offered at SMU; to describe the unique experience of the author with the assessment of medical students during this selective, and to outline the structure of the selective in a way that might serve to assist other schools in the development of similar selective. It is the opinion of the author that offering medical students an opportunity to function as medical volunteers is good for their medical training and is also an effective way to influence their career decisions, leading to an increased desire to work with underserved populations and a higher likelihood of choosing a carrier in primary care medicine [3].

\section{APROACH}

\section{Context}

At Sefako Makgatho Health Sciences University, the third-year curriculum includes Selective courses which are compulsory for the medical students. A list of the available Selective modules that would be facilitated by various lecturers within the university is made available to the students at the start of each academic year [9]. These selective courses are credit bearing courses which must be passed by the medical students in the 3rd academic year in order to proceed to the 4 th year [4,9]. Selective or elective courses provide a unique learning experience that is selfdirected with emphasis on personal responsibility for such learning experience, which subsequently encourages innovation and leadership through a tremendous variety of learning experiences $[1,3,5]$. Selective in undergraduate medical curriculum at Sefako Makgatho Health Sciences University (SMU) provides a unique opportunity for medical students to enroll in an optional module that is outside the core of the medical curriculum [9]. This selective provides flexibility to the students in pursuing an area of interest that appeal to them beyond the confines of basic and clinical medicine [1-4].

The selective, entitled "Medical Volunteerism" was offered as one of 25 third year selectives during the 2016 
academic year [9]. Medical volunteerism entails engagement of the medical students in activities that tied them with the primary burden of providing service to the community where they participate in an organized activity that meets the identified needs of such community $[1,3,7]$. They are required to subsequently reflect on the services they have rendered to the community in need and in the process have a deeper understanding of the reasons for such activities with a view to developing a sense of civic responsibility. The medical volunteerism selective was developed by the author (AOA), a faculty at SMU after a thorough review of the literature and the syllabi of $3 \mathrm{rd}$ year courses in order to have the appropriate frame of reference from which to design the course content and practical activities [8,9,10,11]. The facilitator ensured that the course content correlated well with the level of knowledge of the 3rd year medical students in terms of theoretical and clinical skills expected of a preclinical medical student. This medical volunteerism selective specifically provides a unique opportunity for the undergraduate medical students to impact the communities around them, allowing them to utilize their skills and knowledge to solve some of the common societal problems around them thereby making the society a better one $[1,7,12]$. The flexibility of medical volunteerism selective course makes it difficult to assess the performance of medical students unlike other traditional courses within the medical curriculum where the activities are well defined, and assessment is easily carried out.

It is a well-established fact that assessment is an important aspect of medical education and training through which the competency of the examinees is ascertained. Usually made up of testing, measuring and providing feedback to students; the goals of assessment are to provide direction for future learning, meet public expectation of high professional standard by weeding out incompetent trainees, and choose trainees who can advance their training $[2,4,6,10]$. Although a good assessment should be valid or coherence, consistence, equivalence, feasible, acceptable and possesses both educational and catalytic effects on the examinees [2,6], there is no single set of criteria that apply equally to all assessments; all varies depending on the situations and purpose of the assessment $[2,6,10]$. Therefore, assessment is better conducted using multiple methods, and in different contexts to capture various aspects of the students' performance as an on-going process $[6,8,10]$.

\section{THE COURSE}

\section{Content, Structure and Approach}

The selective course was designed in such a way that its facilitation would engage the students in a variety of ways including didactics lectures, discussions, presentations and community visit at a very early phase in the course of the selective for knowledge acquisition and subject immersion $[5,8,11]$. A total of 14 medical students registered for the selective: comprising 5 males and 9 females. The selective periods consisted of a total of 16 hours (eight sessions of 2 hours each) dedicated to lectures, discussions, students' presentations, and community visit. Table 1 below indicates the curriculum outline of the Medical Volunteerism selective. The actual time taken for the students to complete their volunteerism work was not included in the 16 hours due to the various duration of time required by each person to carry out their work. The learning outcomes were made available at the beginning of the course together with the competencies expected of the students [9], (See Table 2). The learning outcomes were linked to the Health Professions Council of South Africa (HPCSA) core competencies for undergraduate medical students in South Africa [4]. The core competencies domains were used in outlining the competencies expected of the students after the completion of the volunteerism selective [4,9]. The chosen educational practice was well aligned with assessment modalities to avoid a mismatch between teaching and assessment $[5,8,9,11]$.

Table 1: Curriculum for Medical Volunteerism Selective

\begin{tabular}{|l|l|l|}
\hline Theme & Learning outcomes & Activities \\
\hline Introduction & $\begin{array}{l}\text { Describe Medical } \\
\text { Volunteerism }\end{array}$ & $\begin{array}{l}\text { Lecture and group } \\
\text { discussion }\end{array}$ \\
\hline Concepts & $\begin{array}{l}\text { Explain key concepts } \\
\text { of Medical } \\
\text { Volunteerism }\end{array}$ & $\begin{array}{l}\text { Lecture and group } \\
\text { discussion }\end{array}$ \\
\hline $\begin{array}{l}\text { Social } \\
\text { activism }\end{array}$ & $\begin{array}{l}\text { Differentiate between } \\
\text { Social activism and } \\
\text { Volunteerism }\end{array}$ & $\begin{array}{l}\text { Lecture and group } \\
\text { discussion }\end{array}$ \\
\hline Importance & $\begin{array}{l}\text { Illustrate the benefits } \\
\text { and challenges of } \\
\text { Volunteerism }\end{array}$ & $\begin{array}{l}\text { Lecture and group } \\
\text { discussion }\end{array}$ \\
\hline Ethics & $\begin{array}{l}\text { Understand ethics of } \\
\text { Medical Volunteerism }\end{array}$ & $\begin{array}{l}\text { Lecture and group } \\
\text { discussion }\end{array}$ \\
\hline $\begin{array}{l}\text { Community } \\
\text { diagnosis }\end{array}$ & $\begin{array}{l}\text { Identify health need(s) } \\
\text { of an underserved } \\
\text { community }\end{array}$ & $\begin{array}{l}\text { Outreach activities and } \\
\text { community engagements }\end{array}$ \\
\hline Projects I & $\begin{array}{l}\text { Offer practical health } \\
\text { promotion strategy / } \\
\text { solutions }\end{array}$ & $\begin{array}{l}\text { Presentations, feedback, } \\
\text { discussion, reflections, } \\
\text { and evaluation }\end{array}$ \\
\hline Projects II & $\begin{array}{l}\text { Implement the } \\
\text { identified health } \\
\text { promotion strategy }\end{array}$ & $\begin{array}{l}\text { Presentations, feedback, } \\
\text { discussion, reflections, } \\
\text { and evaluation }\end{array}$ \\
\hline
\end{tabular}

During the course, the medical students learn about volunteering which is an expression of the individual's involvement in their community $[1,7,11]$. Volunteering activities were not restricted to the university environments only and students were at liberty to choose any suitable environments for their volunteering work. In the course of doing any volunteerism work the students were told to bear these three things in mind. Firstly, the action should be carried out voluntarily, according to an individual's own free will, and not as an obligation stipulated by law or contract. Secondly, the action should not be undertaken primarily for financial gain or reward, and thirdly, the action should be for the common good of the community. The facilitator ensured that all the students participated actively during the class discussion and community engagement. This sustained the levels of enthusiasm among the students and enabled the group to work interdependently most of the time. After the community visit the students were allowed time to reflect on the activities done so far and come up with various projects proposals, they felt would assist in addressing the various gaps in service identified in the earlier community visit. The students further conducted independent research into the practicability of their proffered solutions and subsequently each made presentations of their proposals to the whole group with constructive critique from both the facilitator and students alike. After the presentations, the students were asked to refine their proposals and after this, they all carriedout their individual projects and group projects in the 
communities identified by them. These projects were done within three months period after the proposals were accepted by the facilitator. Some of the activities undertaken by the medical students include the following:

- $\quad$ Screening for hypertension, diabetes mellitus, and high cholesterol and obesity among and underserved population.

- Provision of winter blankets for children and adults in a rural community.

- Renovation of a dilapidated orphanage building.

- Health promotion and disease prevention activities among high school students.

- Career guidance and role modelling at a rural secondary school.

- Volunteering as health assistant at a local hospice

Table 2: Enabling Competency Domains of the course

\begin{tabular}{|c|c|}
\hline 1. & Identify health need(s) of a community \\
\hline 2. & $\begin{array}{l}\text { Identify health promotion or strategy for disease } \\
\text { prevention in the community }\end{array}$ \\
\hline 3. & $\begin{array}{l}\text { Act as an advocate for the population identified with } \\
\text { health needs }\end{array}$ \\
\hline 4. & $\begin{array}{l}\text { Share tasks with group members to assess health needs of } \\
\text { the community }\end{array}$ \\
\hline 5. & $\begin{array}{l}\text { Collaborate with the community to plan and solve their } \\
\text { health problems }\end{array}$ \\
\hline 6. & Work interdependently within the group \\
\hline 7. & $\begin{array}{l}\text { Demonstrate respectful attitude towards other members } \\
\text { of the group }\end{array}$ \\
\hline 8. & $\begin{array}{l}\text { Reflect on how to improve interaction with others and the } \\
\text { community }\end{array}$ \\
\hline & $\begin{array}{l}\text { Employ collaborative negotiation skills to achieve } \\
\text { consensus }\end{array}$ \\
\hline 10. & Demonstrate appropriate leadership within a team \\
\hline 11. & e pop \\
\hline
\end{tabular}

\section{Course Assessment}

Assessment drives learning but the flexibility nature of the selective courses makes them difficult in terms of assessing performance of medical students, therefore it is often necessary to use a combination of methods to enable one to capture the various aspects of students' performance [6]. In light of the above, the following assessment modalities were chosen for the selective course: firstly, observation of students during volunteering activities, secondly, oral examination in form of viva voice; thirdly, written examinations made up of Multiple Choice Questions [MCQs] and short answer essay, and lastly, Case-reports of projects carried out by the students $[2,6,10]$.

Table 3 below depicts the outline of how these assessment modalities were applied. The observations were done by the facilitator using a checklist of items that are expected of the students after attending lectures, participating in all activities, and completing the volunteering projects. The oral examinations took the form of viva voice where students were asked to describe some concepts of medical volunteerism. Some scenarios were also relayed to the students and they were asked to identify and provide solutions to the obvious gaps in service of some underserved communities.

The written examination included MCQs and short-answer essay questions on all aspects of the topics covered during the class lectures including some ethical issues associated with volunteerism in general [12]. The final aspect of the assessment was the written case-report compiled by each student detailing their volunteerism work. Marks were awarded based on pass-fail pattern and all the 14 medical students performed exceptionally well with all the scoring above $60 \%$ in their final marks.

Table 3: Assessment domains and mode of Assessment

\begin{tabular}{|c|c|}
\hline What to assess & Assessment Mode \\
\hline $\begin{array}{ll}\text { Habits of mind and behaviour } \\
\text { 1. } & \text { Attendance } \\
\text { 2. } & \text { Punctuality } \\
\text { 3. } & \text { Class participation } \\
\text { 4. } & \text { Reflection }\end{array}$ & $\begin{array}{l}\text { Observation } \\
\text { Oral examination } \\
\text { Written examination } \\
\text { Portfolio } \\
\text { Self-assessment }\end{array}$ \\
\hline $\begin{array}{l}\text { Knowledge acquisition and application } \\
\text { 1. Community engagement } \\
\text { 2. Innovation and ideas } \\
\text { 3. Ability to identify gap in service in } \\
\text { underserved populations } \\
\text { 4. Ability to identify health promotion } \\
\text { strategy for disease prevention } \\
\text { 5. Advocacy for the population identified } \\
\text { with health needs } \\
\text { 6. Service to the identified population }\end{array}$ & $\begin{array}{l}\text { Observation } \\
\text { Oral examination } \\
\text { Written examination } \\
\text { Case reports } \\
\text { Portfolio } \\
\text { Self-assessment }\end{array}$ \\
\hline $\begin{array}{ll}\text { Communication skills } \\
\text { 1. Interdependent work } \\
\text { 2. Collaborative negotiation skills } \\
\text { 3. Demonstration of respectful attitude } \\
\text { towards others } \\
\text { 4. Leadership skills } \\
\end{array}$ & $\begin{array}{l}\text { Observation } \\
\text { Oral examination } \\
\text { Written examination } \\
\text { Case reports } \\
\text { Portfolio } \\
\text { Self-assessment } \\
\end{array}$ \\
\hline $\begin{array}{l}\text { Professionalism } \\
\text { 1. Interdependent work } \\
\text { 2. } \quad \text { Leadership skills }\end{array}$ & $\begin{array}{l}\text { Observation } \\
\text { Oral examination } \\
\text { Portfolio } \\
\text { Self-assessment }\end{array}$ \\
\hline \begin{tabular}{ll}
\multicolumn{2}{l}{ Teamwork } \\
1. Interdependent work \\
2. \\
3. \\
4. $\quad$ Dollaboration sharing \\
towonstration of respectful attitude \\
towards others \\
\end{tabular} & $\begin{array}{l}\text { Observation } \\
\text { Oral examination } \\
\text { Written examination } \\
\text { Case reports } \\
\text { Portfolio } \\
\text { Self-assessment } \\
\end{array}$ \\
\hline
\end{tabular}

\section{Outcomes}

Feedback from the students and some stakeholders was taken after the completion of the selective using a course evaluation form. The end of course evaluations from all the sessions were strongly positive, with students rating the sessions highly in a variety of instances, including appropriateness of the lecture topics, presentation of the course contents, level of material, effectiveness of teaching and level of students' participation. The average overall rating for the course was 8.4 based on a ten-point scale. The survey also made allowance for the students to make additional narrative comments, included among the students' comments were that "medical volunteerism has opened my eyes to an important aspect of medical practice that is often neglected"; "I will consider working in primary care after graduation"; "Medical Volunteerism should be made compulsory for all medical students". Additionally, some of the students also commented that they had intention to continue doing some form of medical volunteerism as time permits until they complete their medical studies. Others acknowledge that they have better understanding of what social activism in health entails and what it means to be referred to as a health advocate after the course. All these point to a successfully completed selective course which happened to be new and unique to the medical school. 


\section{DISCUSSION}

The medical volunteerism selective described in this article provide information about the organization, implementation and outcome of the selective course which is valuable to other medical schools that are trying to create selective courses. It represents a model of self-directed learning opportunity that provides medical students with earlier exposure to medical volunteerism which is a gateway to many hidden opportunities; through volunteering individuals network, gain skills and experience that allow them to make impact in other people's lives [12,13]. Volunteering is an avenue that allows someone to gain practical experience working in a field they are interested in; thereby developing important skills that could be necessary for their future career $[10,12]$. Because medical students received credits for the activities done during the medical volunteerism selective, technically they are not regarded as 'true volunteers' but they function as such from the perspective of the designer of the medical curriculum. In other terms, one could have referred to the course as a service-learning course.

A significant amount of time, energy and involvement is necessary for the planning of this selective. This is important to ensure that this learning experience is a valuable one for the students and not simply an opportunity to indulge in wasteful activities. Given the well outlined course curriculum, itemized competencies, oral presentations, coherent approach to assessment, final written reports, and evaluations, the selective was well accepted and has grown in popularity among the staff and students. This selective increased the measured knowledge of the medical students that participated in the course. Certain knowledge and skills that are not available within the traditional medical school curriculum were attained by the students; therefore, it is evident that the selective taught them useful skills that could influence their future career choice and place of work $[1,12,13]$.

One of the few challenges associated with assessment that are not often mentioned include how to assess professionalism and teamwork in terms of performance among medical students. These two components are essential element of competence, although there is no simplified validated tool available to easily measure them [6]. This made the traditional assessment methods of using written and oral examinations to be insufficient for this kind of selective as certain performances such as teamwork and professionalism are difficult to assess using these traditional modes of assessment $[2,6,10]$. Therefore, the use of multiple methods of assessment is highly relevant and appeared invaluable in this selective course. Future attempt at assessing these competency domains should have a checklist or benchmark from which one can easily assess performance of competency which appears to be abstract like teamwork and professionalism.

\section{CONCLUSION}

From the experience illustrated in this selective, it has been shown that selective courses have positive impact that is measurable, and it could complement the core medical curriculum. It is therefore recommended that support should be given to students and facilitators who are interested in implementing medical volunteerism selective within the medical curriculum. This will ensure the production of medical doctors who are well-rounded in medical training and have an increased desire to work with underserved communities which are seen in all human populations around the globe. In the word of an author, selective in medical education can make a lasting impression on the participants, altering their perceptions of healthcare, societal and personal responsibility $[12,13]$. Finally, by highlighting the organizational structure of the medical volunteerism selective at SMU, the contribution of this paper is to provide resource and stimulus for the development of such selective at other medical school. It is also hope that this article will encourage the write-up of similar papers by faculty or students involved in medical volunteerism selective in various medical schools at worldwide.

\section{ACKNOWLEDGMENT}

The author would like to thank all the medical students that participated in the medical volunteerism selective course during the 2016 academic year, the management of the University for administrative and logistical support. In addition, the author would like to acknowledge the assistance provided by the various communities visited by the students during the community outreach activities.

\section{REFERENCES}

[1] Agarwal, A. Wong, S. Sarfaty, S. Devaiah, A \& Hirsch, AE. Elective courses for medical students during the preclinical curriculum: a systematic review and evaluation. Med Educ Online 2015; 20: 26615.

[2] Epstein, RM. Assessment in Medical Education. N Engl J Med. 2007; 356:387-396.

[3] Federico, SG, Zachar, PA, Oravec, CM. A Successful International Child Health Elective. Arch Pediatr Adolesc Med. 2006; 160:191-196.

[4] Health Professions Council of South Africa (HPCSA). Core competencies for undergraduate students in clinical associate, dentistry and medical teaching and learning programmes in South Africa. 2014. Pretoria. South Africa

[5] Josephson, SA \& Whelan, AJ. A New First-year Course Designed and Taught by a Senior Medical Student. Acad. Med. 2002; 77:1207-1211.

[6] Norcini, J. Anderson, B. Bollela, V. Burch, V. Coasta, MJ. Duvivier, R. Galbraith, R. Hays, R. Kent, A. Perrott, V \& Roberts, T. Criteria for good assessment: Consensus statement and recommendation from the Ottawa 2010 Conference. Med Teach. 2011; 33:206-214.

[7] Northrup, R. Preparing students for overseas elective. Acad Med. 1991; 66:92.

[8] Schober, A. Pieper, CC. Schmidt, R. \& Wittkowski, W. "Anatomy and Imaging": 10 Years of Experience with an Interdisciplinary Teaching Project in Preclinical Medical Education - From an Elective to a Curricular Course. Fortschr Röntgenstr 2014; 186: 458-465.

[9] Sefako Makgatho Health Sciences University. MBCHB III: Special Study Selective Learning Guide 2016; Pretoria. South Africa.

[10] Shumway, JM \& Harden, RM. AMEE Guide No. 25: The assessment of learning outcomes for the competent and reflexive physician. Med Teach. 2003; 25:569-584.

[11] Sobral, DT. Cross-year peer tutoring experience in a medical school: conditions and outcomes for student tutors. Med Educ. 2002; 36:10641070.

[12] Stone, GS. \& Olson, KR. The Ethics of Medical Volunteerism. Med Clin N Am. 2016; 100:237-246.

[13] Yeh, AC. Franko, O \& Day, CS. Impact of Clinical Electives and Residency Interest on Medical Students' Education in Musculoskeletal Medicine. J Bone Joint Surg Am. 2008; 90 (2): 307 -315. 


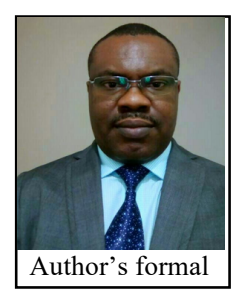

Dr AO Adefolalu $(M B C H B, M P H, P h D$ is with the School of Medicine at Sefako Makgatho Health Sciences University, South Africa. A Public Health

Physician, his research interests include Clinical epidemiology, International Health, and Medical Education. He is associate editor and reviewer of highly ranked scientific journals. He mentors undergraduate and postgraduate students, and he is actively involved faculty development. 